\title{
Analysing Social Partnership: \\ A Tool of Union Revitalization?
}

\author{
MICHAEL FICHTER \\ University of Berlin \\ AND \\ IAN GREER \\ Cornell University
}

\section{INTRODUCTION}

Recently, much has been written about social partnership. Especially in Europe, the spread of national social pacts, the introduction of tripartite institutions to the Central and Eastern European accession countries, and the implementation of the Social Dialogue in the European Union have created a new interest in the effects and effectiveness of such arrangements. In the United States, the meaning of labour-management partnership is developing further, as revitalized unions of service and construction workers have applied this instrument to extend and consolidate gains (Mills 2001; WAI 2002).

This chapter focuses on one issue among many with regard to social partnership: When can it be a tool of union revitalization? In the past, critics close to the labour movement associated social partnership with a stagnant and defensive brand of unionism that was out of touch with the working class, overly concerned about ongoing relations with the state and capital, and incapable of carrying out a contentious role in class struggle and pluralist industrial relations (Parker and Slaughter 1994; Kelly 1998). More recently, critical voices have taken a more contingent approach by using different union capacities (Parker and Slaughter 1997) and differing product and labour market conditions (Kelly 2004) to explain varying outcomes of partnership experiences for unions and their members. Using evidence from five countries, we find that social partnership contributes to revitalization, when it is institutionalized, integrated with other union strategies, and, most importantly, when it is pursued in the interest of a broader social agenda.

Just what do we mean when we use the term 'social partnership'? For one, we define it as a kind of interaction between unions and employers (Turner 1998) and not as Kjaergaard (2001: 9) does, as including the whole range of other civil society organizations. While other organizations often play important roles, the core of the partnerships we are discussing consists of formally structured, ongoing relations of cooperation ${ }^{1}$ between unions and employers, whether at the national, regional, or sectoral level between unions and employer associations, or within enterprises between worker and management representatives. Second, social partnership has a policy agenda, which can cover a wide range of issues, usually including 'mutual gains'. These may be part of efforts to reform collective bargaining itself (such as setting up frameworks for continuous 'integrative bargaining' inside or beyond the workplace), but the agenda can also include issues outside the usual focus of collective bargaining (i.e. in-house training or political issues) as well as social policy goals that 
extend beyond the two social partners (such as labour market integration, equality of opportunity, regional economic development, and welfare state reform). Lastly, social partnership requires that labour and management be able and willing to apply sanctions on unilateral violations of cooperation by the other side. To this end, unions can use partnership, when part of a larger repertoire of strategies, to bolster their own bargaining position, especially of local unionists participating in workplace change. Social partnership relations, then, can satisfy our basic definition and feed into union revitalization while differing across structural, functional, and strategic dimensions.

Historically, strong union movements have been able to use their organizational and mobilization capacities to work with employers and government and institutionalize their successes. The institutional framework of social partnership, which they have helped to create, can include codetermination legislation at workplace level, national corporatist structures, or cooperative collective bargaining arrangements at industry or regional level. This framework has not only served union-specific agendas, but has also been the foundation for implementing wider public policy goals such as solidaristic welfare and labour market re-integration programmes as well as company/workplace- level employee participation. A strong institutional framework with extended union participation is, we argue, a prerequisite for functioning social partnership. However, it is not sufficient and can sometimes even prevent unions from developing or implementing innovative strategies. Therefore, social partnership is more likely to contribute to union revitalization when it is complementary to the strategies and autonomous organizational capacities of unions. In other words, unions should use their own resources and skills to counter or prevent attacks from governments and employers as well as to pursue partnership proactively and strategically. Institutionalized partnership activities in conjunction with the broader array of union activities, however, are not enough; 'doing it alone' with management can strengthen unions in their old strongholds but it can also engender particularism in political action or bargaining activity. For an integrated strategy to promote revitalization, the partnership also has to serve a broad social agenda that appeals to allies both in particular communities and in the general socio-political arena. Examples of such agenda-setting would include efforts to combat unemployment at the national level or to eliminate discrimination against immigrant workers.

Social partnership arrangements are most conducive, we argue, to furthering union revitalization in cases that meet these three criteria. In other words, they need to be institutionally embedded, they must be integrated into a proactive union strategy, and they should pursue a broader social agenda rather than focusing on narrow union-specific issues alone. In terms of Behrens, Hamann, and Hurd's (Chapter 2, this volume) definition of union revitalization, these kinds of partnerships may strengthen labour's political influence, its bargaining power, membership density, and other indicators of organizational 'vitality'. By contrast, absent a solid anchor of supportive institutions and union strategies and a link to broader social initiatives, social partnerships usually strengthen the interdependence between unions and specific firms, thus remaining particularistic, thwarting the embeddedness of partnership in a broader social environment. While we find our argument applicable in the five national contexts, it is based on a reading of evidence in which cases meeting our three preconditions are few and far between. This is as much a statement about the still limited occurrence of union revitalization as it is a reflection of the limited use of social partnership as a tool to this end.

In Italy, Spain, and Germany, confirmation of this argument comes not only from the historical accomplishments 
of labour and management establishing widely valued policies for welfare provision and worker participation, but also from recent stumbling blocks with national-level social partnership. Our argument helps to understand organized labour's reaction to more recent neo-liberal policy orientations in these countries. The neo-liberal turn in national policy-making may have weakened labour's supportive institutional environment, and has certainly stirred debate over the pitfalls of continued cooperation with capital in national competitiveness pacts. At the same time, labour movements have learned to focus partnership activities in other arenas, such as firms and regions. This shifting paradigm raises two possibilities. First, labour's institutional embeddedness may be, paradoxically, both a prerequisite for, and retardant of, union revitalization, in the sense that unionists may be finding that the heavy reliance on institutionalized social partnership has led to the neglect of other strategies (Baccaro, Hamann, and Turner 2003), and an isolation in broader society. Second, new subnational loci of action have their own limitations from the point of view of union strategy, by only being useful within existing union strongholds and by increasing the problems of decentralization (Schroeder and Weinert 1999; Artiles Martin, and Moner 2003).

After a short review of the literature on social partnership and union revitalization, the chapter goes on to analyse the evidence on social partnership in five countries.

\section{PARTNERSHIP, UNIONS, AND UNION REVITALIZATION: AN OVERVIEW OF THE LITERATURE IN ENGLISH}

Analyses of the prospects and dimensions of social partnerships in countries without an institutionalized tradition of cooperative labour relations (such as the United States and the United Kingdom) have provided insights into the problems unions face under such conditions when the balance of power between labour and management is notably unequal. ${ }^{2}$ The 1980 s marked the appearance of a great number of new publications on labour-management partnerships in the United States. Initial findings showed that management was increasingly able to define cooperation' on its own terms based on a new strategy to decentralize bargaining and make labour-management relations more flexible and differentiated by sector, firm, and by workplace (Katz 1993). Changes in industrial relations systems were driven by the 'strategic choices' of' management (Kochan, Katz, and McKersie 1986; Walton, Cutcher-Gershenfeld, and McKersie 1994). Unions faced with demands for wage concessions and cooperation in the upgrading of production methods were obliged to accept the implementation of new human resource practices emphasizing cooperation and de-emphasizing protective shop-floor rules. Although this literature pointed to union role changes (Katz 1985) and to how union members could benefit from linking local labour-management partnerships to national policies (Frost 2001), it did not systematically follow up on how unions could transform choices made in hard times into opportunities for renewal. At the same time, another segment of the literature argued that partnerships reinforced the subordination of union organizations to management (Wells 1987; Parker and Slaughter 1994). The discontent with partnership as a union strategy resonated with the British literature, beginning in the early Blair years, which focused on a wave of firm-based partnerships (Guest and Peccei 2001). Critics further asked whether unions were being forced into partnership by economic trends beyond their control (Klare 1988); how partnership could serve a strategic purpose on the new 'terrain' of modern production organization (Banks and Metzgar 1989); and how, specifically, unions could harness partnership activities to support other 
goals such as member involvement (Juravich 1998). As such, the Anglo-American literature pointed out the problems of partnership for unions without being able to conclude whether unions could reverse their decline in partnership with employers.

In contrast, the literature on Europe brought out important national differences in the extent to which firms could implement change unilaterally and in the ability of unions to work strategically with social partnership. The case of Germany in particular, with its dual system of interest representation, showed how different institutions could promote social partnership and lead to better outcomes, both for workers and for the economic vitality of the country (Streeck 1984; Turner 1991). Subsequent developments in the comparative political economy literature suggested that industrial relations institutions (and hence patterns of partnership and conflict) were closely related to other features of national political economies, such as financial markets, welfare states, and skill provision (Hall and Soskice 2001). But as Turner (Chapter 1, this volume) has noted, these authors tend to see union strategy as unimportant and overlook the importance of subnational arenas that constitute union activity in a given country (Christopherson and Storper 1987; Locke 1992). The comparative industrial relations literature thus found national variation in union strategies linked to a broader institutional context, without being able to conclude the extent to which essentially subnational phenomena driven by unions, such as instances of union revitalization, could be explained by national characteristics. Moreover, it seemed that the applicability of traditional comparative political economic theory outside of 'corporatist' or 'coordinated market economies' such as Germany, was questionable (Thelen 2001; Baccaro 2002).

Union revitalization as a central concern has only recently been addressed in the literature. To be sure, the revitalization literature has not systematically assessed the impact of labour-management partnership on the vitality of unions. But its presentation of the many and diverse instances of the revitalization phenomenon (Mills 2001) allows us to analyse the concrete actions of unions in partnership, such as building new institutions, seeking new allies, pursuing new policies, and strategiz- ing in ways that link the array of activities. On this basis, we can change the question from 'is partnership good or bad' to 'under what conditions do partnerships feed into or frustrate revitalization' and look beyond broad national trends to phenomena in specific firms and local sectors. The cases below illustrate how our argument, based on this actor-centred re-reading of industrial relations literature, helps us to understand the dynamics of partnership and union renewal.

\section{US AND BRITISH PARTNERSHIP AGREEMENTS AS ISOLATED PROJECTS}

In the United States, where the term 'labour-management partnership' is generally used, most writings on this topic have little to say about union strategy, because unions have usually signed on to cooperative projects with management when they had no other options. During the 1980s and 1990s, for example, unions in troubled auto, aircraft, and steel firms sought out and developed surprisingly strong relations of partnership with firms. Such arrangements, shaped by firm-level collective bargaining frameworks and supplemented with in-plant agreements, benefited some union members by paying for skill development for both internal and external labour markets, by modernizing human resource policies, and increasing job security (Gray, Myers, and Myers 1999). Such partnerships have, in some cases, included 
'neutrality' provisions that extend new organizing rights to workers in some non-union plants (Eaton and Kriesky 2001) and recognize a union role in the introduction of 'sensitive' or 'lean' systems of production. As the 1998 General Motors strike showed, this put massive disruptive power in the hands of some workers (Herod 2001).

This kind of 'new industrial relations', however, did not usually protect unions from membership loss or stop the decline of unionized industries. Employers used bankruptcy proceedings and the creation of non-union subsidiaries to negotiate further concessions and cuts, shrinking the number of workers who benefited from partnership. As such, labourmanagement partnerships were not the main cause of union organizational decline, but at least in the manufacturing sector, they also did not turn the tide in favour of revitalization. Most commentators within the labour movement have accepted partnerships as a fact of life, and a few have begun to ask how unions can develop the kinds of rule-based partnership that could protect participants and feed into other strategies (Banks and Metzgar 1989; Juravich 1998).

In other sectors, such as construction, health care, hotels, and entertainment, unions have begun to shift towards a more strategic use of partnership by incorporating partnerships with employers into local political action, coalitions with communities of immigrants and racial minorities, and other revitalization strategies (WAI 2000, 2002). Construction unions, for example, suffered considerable membership losses during the recessions of the 1970s and 1980s when hundreds of thousands of unemployed union members accepted lower-paid jobs in the non-union sector, the growth of which had been abetted by public and private owners of construction projects seeking lower prices (Erlich 1986; Linder 1999). Attempts since the 1990s to organize increasingly non-white construction workers have benefited from more favourable market conditions, but have also had to overcome a history of racial exclusion from the unionized trades. By the late 1990s, construction unions throughout the country had begun to heal relations with urban community groups and become important players in local politics, able to influence contract awards over construction projects and real estate development. In this way they succeeded in increasing their membership while most unions were in decline. Employers played a supporting role in these efforts by contributing to the modernization of recruitment and training structures and the development of supportive public policy instruments.

The union-led labour-management partnership in Seattle's construction industry illustrates this approach. Beginning in the 1990s, a consortium of local craft unions organized collectively as the local building and construction trades council and - together with unionized contractors, who had an interest in expanding their share of the market and improving jointly administered apprenticeship programmes - approached private and public customers of building contractors, asking them to sign project labour agreements (PLAs). These were designed to reduce cost overruns and delays while upholding specified minimum standards for working conditions (e.g. wages, health and safety) defining procedures to resolve jurisdictional disputes between craft unions, and eliminating inefficient work rules. Through the widespread recognition of PLAs, the unions sought to prevent non-union contractors from being able to win contracts through wage dumping (Northrup 1997). When opponents attacked PLAs and put pressure on government officials to reject or cancel such agreements, the unions built community support by expanding the rationale for PLAs beyond that of mutual gains for the union, contractors, and customers, to promote racial and gender diversity in the workplace and investment in skills training. 
By advocating rules to include 'labour market outsiders' in relatively well-paid construction jobs, Seattle unions have built community pressure for PLAs while healing old wounds with the black and Latino communities. Unlike most workers in the United States, unionized construction workers normally undergo formal occupational apprenticeships, combining on-the-job with classroom training; accordingly, the PLAs mandate the use of apprentices on large construction sites. By coupling apprenticeship rules with racial and gender diversity targets, the agreements open job opportunities for traditionally excluded groups. Organizations of minority groups helped to convince authorities to sign PLAs by testifying at public hearings that the agreements would create first-rate training opportunities for minority workers who had until then been consigned to second-rate jobs in the non-union sector. The unions pushed the concept further by including an on-the-job mentorship programme to protect new workers from the usual 'sink or swim' demands, which usually lead to high dropout rates from apprenticeships.

Since the early 1990s, PLAs have been successfully implemented at several large projects in Seattle (and many other major cities), ${ }^{3}$ including a new airport runway, new public buildings, and even some private projects (WAI 2002). By linking their own partnership and market expansion strategy with workplace diversity, broadly recognized as a valuable public policy goal, Seattle's construction unions have extended the bounds of typical labour-management partnerships beyond the achievement of 'mutual gains' for employers and unions by recruiting, training, and providing on-the-job supports for new workers. Downward wage pressure has been reduced as non-union firms, although not formally excluded from contract bidding under PLAs, have lost their ability to win contracts through low bids based on low pay. As PLAs have become more widespread and union contractors have sought more employees, we can assume that union density on large building projects has increased, although exact numbers are not available. Furthermore, healing old wounds with minority groups and the establishment of a network of public policy experts working in union offices, who specialize in framing, passing, and implementing union-driven upgrading-directed local economic development projects, has helped strengthen the unions' influence in local politics. This is superimposed on top of decades-old practices of sectoral collective bargaining and jointly governed training institutions. Broadening the agenda, integrating partnership with other strategies, and using a longstanding role in training have led to more political influence and more union members, both of which indicate union revitalization, although quantitative measures are not available.

The link between social partnership and broader coalition politics is unusual in the United States, especially outside the building trades, primarily due to the focus on arrangements for achieving mutual gains' within a specific firm. Manufacturing unions could follow the coalition approach as well to overcome their inability to integrate partnership with other strategies and to attract and retain high wage, eco- friendly 'good jobs' in troubled industrial regions (Leroy 2002). They do not usually do so, however; instead, they tend to favour in-plant forms of participation to save firms. Service sector unions might do the same through living wage campaigns to reduce wage-based price competition among government contractors, and through sector-specific initiatives (Reynolds 2002). In health care, for example, this entails passing laws such as minimum staffing standards that improve the quality of both treatment and jobs (Mills 2001). Unfortunately, much of the partnership in the service sector is beset by a form of 'mutual gains' between one set of workers and an employer, whose strategy for competitiveness brings partnership unions into conflict with other interested 
groups such as consumer advocates, and other unions (CNA 2002). American union strategy development faces an additional, more fundamental problem: outside the union strongholds discussed above, partnership is generally not converted into long-term, rule-bound behaviour, and succumbs either to conflicts of interest within the union camp (Preuss and Frost 2003), or to 'defections' by employers brought on by unsuccessful business strategies (Frost 2001).

British unions have been historically steeped in the ways of adversarial labour relations. Coming from a political and economic environment generally hostile to their inclusion in both managerial and political decision-making processes, they have-like their counterparts in the United States-been wary to embrace the opportunities and challenges associated with partnership strategies. While there is some evidence that this may be changing (Arrowsmith 2002), it is still questionable whether a growing openness toward partnership will actually meet the Trades Union Congress (TUC's) 'acid test' of partnership by yielding improvements in job security, transparency, involvement, and the quality of working life (Martinez Lucio and Stuart 2002). Not the least, this is the result of the fact that British unions have been facing a dearth of opportunities to link partnership with other strategies, largely because the move towards partnership as a proactive approach has not originated with them but with their counterparts in government and large corporations.

Nevertheless, since New Labours ascendancy to power in the late 1990s, and despite reservations (and even outright opposition in some union quarters), some unions have signed on to such 'social partnership agreements' in large firms. The core components include flexibility for the company (task, time, pay, and staffing levels), union rights to information and consultation, and assurances of job security for existing union members coupled with training programs (Heery, Kelly, and Waddington 2003). Participating unions favour such agreements because they tailor the provision of training to the individual employee through 'on-the-job' programmes with wage subsidies. Moreover, these agreements sometimes give unions a role in local and national consultative bodies. In one case, at a newly opened Tesco store in a depressed section of Leeds, the shopworkers' union, USDAW, was involved from the beginning in a variety of workplace development programmes. These included such activities as monitoring both the quality of the training, assuring that skills were transferable and useful on external labour markets, and the working conditions at the store as well as implementing provisions for the payment of 'rate-for- the-job' to trainees. The union also negotiated the hiring of 160 unemployed people from the neighbourhood (Andersen and Mailand 2002). In addition to creating jobs for previously unemployed, non-union persons, this agreement presented an opportunity to attract new members and build bridges to an excluded community neighbourhood without threatening the existing membership with potential job loss. By comparison, an account of the partnership at the employment agency Manpower suggests that British attempts for 'high road' strategies outside the core of union members can conflict with the interests of the union's traditional constituency (Heery et al. 2004).

Besides the changes in the British political environment, which have affected labour, the current interest in developing corporate governance systems has also made an impact on union approaches by fostering steps towards the inclusion of union representation in company decision-making processes. Although the foundations of labourmanagement partnerships are often based on company initiatives to develop such systems, evidence provided by some studies shows that both the effectiveness and the duration of such agreements are strongly influenced by the product and 
service quality rules they engender. When these force firms to upscale their operations, managers must convince shareholders of the long-term benefits to be accrued from sustained cooperation with the union. In addition, cooperation hinges on the strategy perspective developed by management and directors as well as on the continuing availability of a strong, cooperative union (Deakin et al. 2002). At the same time, this environmental support would seem to reciprocally contribute to augmenting union power.

Still, scepticism abounds regarding the kinds of partnerships developing and the postulated link between partnership and union revitalization. First, research has concluded that there is only sparse evidence connecting partnership to the outcomes we might associate with a revitalized labour movement, such as enhanced wages, job security, or union membership levels. Using matched pairs of cases taken from individual enterprises, Kelly (2004) shows that companies with labour-management partnership agreements do not exhibit better outcomes for workers than those without partnerships. This would seem to derive from the limited, company-based dimensions of these pacts, thus lending credence to the criteria we have advanced for linking partnership to union revitalization. Second, individual firm-level partnerships have been shown to be an inadequate instrument for harnessing management prerogatives over employment and restructuring strategies. Martinez Lucio and Stuart (2002), for example, use survey data and case studies from several sectors to find that partnerships were riddled by unilateral behaviour on the management side (such as outsourcing without consulting the union) and a managerial culture of 'limited transparency' (see also Stuart and Martinez Lucio 2002). Third, although they desire more involvement and less adversarial relations with management, unionists are usually excluded from decisions over investment, training, and staff planning. From a union perspective, partnerships therefore usually have little to offer in the way of fitting a union agenda. Guest and Peccei's (2001) survey of unionists and managers finds that partnerships tend to emphasize the contribution of employees to the enterprise more than employee welfare and vigorous representation.

Taking these critical appraisals into account, the question is which union strategy approaches could overcome the enumerated deficits. How can unions in Britain turn the tide and implement social partnership agreements more attuned to their interests? Beyond the self-evident need for them to become active agents in shaping the meaning of'social partnership' (Ackers and Payne 1998), British unions face the task of integrating this instrument into their primarily adversarial approach to strategy. Whether done by means of parallel organization structures or sequentially (Heery 2002), the effective use of social partnership to bolster unioq revitalization will depend greatly on its coherency with other union policies. As Munro and Rainbird (2000) have pointed out, unions must be in control of the overall impact of partnerships on their strategy. In the case of joint workforce development programmes promoted by public services union UNISON, they show that this kind of 'single issue' form of partnership can be insulated from arenas of conflict and at the same time be linked to member recruitment, work skills training, broadening the bargaining agenda, and training for union activists.

The further evolution of such strategies as well as their accompanying debate will also be impacted by structural and legal requirements mandated by the European Union. Indeed, the 1994 directive on European Works Councils, the recent EU Directive on Information and Consultation of Employees, and the spreading acceptance of the EU Social Dialogue (European Commission 2002) present British unions with new instruments-and challenges-for developing social 
partnership approaches which go beyond the local or national realm. Strengthening cross-border cooperation may enable British unions to link ongoing union organizational efforts at the workplace to the broader issue of the provision of social goods. The TUC has expressed keen interest in this policy at least since the early 1990s (Teague 1989).

\section{GERMANY, ITALY, AND SPAIN: SOCIAL PARTNERSHIP AS AN OVERARCHING PHENOMENON}

\section{Germany}

In contrast to the liberal market economies of the Anglo-Saxon countries, where until recently the designations 'social partners' and 'social partnership' appeared to be 'bizarre' (Hyman 2001 b: 39), both concepts are established terms of labour relations vocabulary in Germany. In the Weimar Republic, but even more so since 1949, they have been used so extensively that to many they have become synonymous with the German model of labour relations. Although especially promoted by the conservative Christian Democrats in the early post-war years of West Germany (Schmidt 1985), emphasizing harmony and integration, the concept of social partnership also has social democratic roots. Here, class conflict has become institutionalized with an ensuing 'deadlock between strongly organized parties' leading to 'pragmatic accommodation... in the interests of mutual survival' (Hyman 2001a: 41), or to 'conflict partnership' as Müller-Jentsch (1999) has labelled it.

Nevertheless, there is not much recent debate in Germany over the ramifications of these potentially conflicting conceptions, nor can it be said that the inclusion of other civil society actors in the future development of social partnership in Germany has received much attention. Indeed, the issue of the impact of social partnership as currently understood on union revitalization has as yet hardly been broached (Behrens, Fichter, and Frege 2003). ${ }^{4}$

Within the dense institutional political and economic network which has grown out of the post-Second World War 'dual system' of works councils and regional-sectoral pattern bargaining, social partnership is a widespread approach, not a matter of single (company) cases (Turner 1998:18-19). Even under changing conditions in which new issues re-format the negotiating field, existing multi-level relations enable pattern agreements, such as training arrangements or new collective bargaining provisions, to develop. Social partnership in Germany is both part of, and an extension of, collective bargaining; it has been institutionalized on a national scale (very much in contrast to the Anglo-Saxon experience) and is practiced throughout the field of employment regulation and labour relations, whether tripartite policy-making in the apprenticeship system, bipartite sectoral bargaining between unions and employers' associations, or company-level codetermination including works councils (and sometimes union representatives) and management. As such, it has a political as well as an economic dimension; the former represented at various times by a number of tripartite and multipartite 'Alliances for Jobs' at the national and regional level (Neumann 2000), while in the latter case, social partnership is generally equated with the arena of company or plant agreements (Mauer and Seifert 2001).

At the political level, the primary focus of such partnerships has been to address the general unemployment problem, while in the company arena, the goal has been to enhance the competitiveness of the targeted companies. The internal union criticisms of participation in the national Alliance for Jobs (1998-2002) and the meagre accomplishments of 
this tripartite partnership during Chancellor Schroeder's first term, and its subsequent discontinuation are telling in the current economic and political situation. Indeed, there is no evidence that this form of social partnership has contributed to union revitalization. Nor have unions explicitly pursued this kind of partnership in the interest of this goal. The regional, multi-sectoral 'territorial pacts', for example, have been viewed by union representatives as being a 'positive' exercise solely because key actors from the region, like banks and employment offices, had participated. Unionists praise the accomplishments of such pacts in providing benefits for workers (Gerlach and Ziegler 2000:433), but the contributing role of the unions to such developments is neither directly visible nor has it been strategically exploited by them. Equally, unions generally have only a secondary role in company-level social partnerships, ${ }^{5}$ the primary actors being the legally mandated company works council and management. At the same time, company agreements may infringe on the comprehensive framework of the sectoral contract (cf. Rehder 2002 with Brecht and Höland 2001: 501); avoiding such pitfalls, which would undermine the application of collective bargaining agreements in the workplace, requires union involvement.

Behrens, Fichter, and Frege (2003) have pointed out several different kinds of initiatives based on labourmanagement cooperation that adapt collective bargaining to address the needs of a differentiated and changing workforce. In contrast to tripartite Alliance politics, these efforts have the potential to assist union revitalization efforts. For example, by improving the job market and making unions part of the solution to the unemployment problem, they support membership recruitment strategies. For the IG detail, one such issue of negotiation has been to create individualized benefit packages tied to options for time off or for training. This has not only produced a regional contract on life-long learning for which the union can claim due credit (Huber and Hofmann 2001), it has enabled the union to gain an organizational foothold in heretofore non-unionized sectors such as information technology. As an instrument of revitalization, the contract has an institutional basis traceable to an agreement reached by the now defunct national Alliance for Jobs (Heidemann 2001), and it presents an opportunity to be integrated with the union's recruitment efforts in this region.

A second topic of collective bargaining has been the creation of new jobs and the re-integration of the unemployed into the labour market. Again, the IG Metall may be singled out in connection with the notable Volkswagen project ' 5000 $X 5000^{\prime 6}$ (Heidenreich 2001; Pries 2002); similarly, the mining, chemicals, and energy union (IG BCE) has negotiated a yearly increase in apprenticeships in the chemical industry during the past round of negotiations (IG Chemie 2003). By stepping up efforts to use collective bargaining to help alleviate the unemployment problem, unions could strengthen the legitimacy of their demands and attract new members. As yet, however, there is no significant evidence of such a development.

A third way in which collective bargaining and employer-union partnerships may contribute to union revitalization is through the negotiation of new job evaluation schemes for determining wage classifications. Although there is no formal discrimination of women within a particular wage category, 'women-preferred' jobs are regularly assigned to lower wage groups. At issue is the elimination of discrimination resulting from gender-biased classifications. In a country notorious for the structural exclusion of women from the labour market, these practices could broaden the appeal of trade unionism 
beyond the currently male-dominated and blue-collar core of union membership. The readiness of unions to actively embrace the idea of 'gender mainstreaming' will contribute to overcoming gender bias and to making union membership more appealing to women (Tondorf 2001).

A fourth area of union collective bargaining activities based on partnership relations with employers revolves around the creation of sectoral pension funds to supplement both company pensions and the state pension system. Metallrente, the joint pension fund of the employers' association Gesamtmetall and IG Metall, established in 2001, is a good example of an innovative partnership that offers long-term economic advantages to all employees in the bargaining unit. Instead of retrenchment and a purely defensive policy towards government cutbacks in the state pension system, the social partners added their own complementary pillar, a sectoral pension fund. With further cuts in the state system likely, this initiative is especially attractive to younger employees, and could help IG Metall recruit new members.

A fifth area of potential union revitalization may grow out of the current restructuring and regulation of the temporary employment field. After several months of bargaining during the first half of 2003 , the unions announced that agreement had been reached on a number of national framework contracts covering temporary employment. Union opposition to the relaxation of restrictions on temporary workers was quite strong until recently, when they lost the battle over government deregulation. At this point, they moved quickly to establish collectively bargained minimum standards. These framework contracts regulate all of the major issues of temporary employment in the interests of the temporary as well as regular employees. While it is still too early to predict how effective these agreements will actually be and how well they will function in practice, they have a potential to improve working conditions in this field and to integrate temporary workers into the representational jurisdiction of the unions, which could enhance the union's bargaining power and support membership recruitment efforts.

These five reforms of collective bargaining show how German unions have used the partnership framework in an innovative way. It is on this plane, the core of union mobilizing capacities and interest representation that some German unions have begun to develop social partnership as a policy agenda for making a strategic contribution to union revitalization. Yet, most traditional alliance politics in the workplace, have, for the most part, been disconnected both from a broad social agenda and the main thrust of union strategy. And at the regional and national level, unions have been unable to effectively rebuff the neo-liberal agenda proposals of employers as government support for their policy proposals has been dwindling.

\section{Italy}

In Italy, recent social partnership developments pose a major challenge to the way that comparative scholars view the impact of institutions and the character of a national trade union movement on the quality of social partnership. The ability to make national tripartite pacts, the development of strong union-driven statutory workplace representation, and the coverage of collective bargaining agreements throughout the economy are testament to the strong institutional position from which unions pursue social partnership in Italy. Italy's labour relations' practices thus appear to be closer to those of Germany than those of the United States or the United Kingdom, even if it does not fit into the category of a 
coordinated market economy' (Hall and Soskice 2001).

For decades, the politicized and antagonistic nature of trade unionism, as well as the highly fragmented character of the labour market, had posed problems for developing a union-backed strategy of social partnership. Baccaro, Carrieri, and Damiano point out that the Italian unions were not able to overcome a paradoxical coexistence' of local cooperation and innovation and national level paralysis regarding political strategies until the $1990 \mathrm{~s}$. At that time, all three confederal unions, the CGIL, the CISL, and the UIL, were facing organizational decline and the rise of new employee associations, when institutionalized social partnership became the primary mode of union revitalization (2003: 121). Following the scandals which discredited the entrenched political parties, the three confederations cooperated to use a window of opportunity to enhance their political participation and to push for economic and political reforms in the interest of their constituencies (Haddock 2002). At the same time, they pursued a strategy of membership involvement in union decisionmaking which allowed them to participate in tough decisions that were bound to adversely affect some part of their constituency. Consensual support for political and economic reforms, which moderated wage growth and temporarily suspended plant-level pay bargaining, was secured by mobilizing an otherwise passive majority through the extension of democratic rights of participation (Baccaro 2001, 2002). As such, the institutional embeddedness pursued by the unions during the 1990s supported a strategy of membership mobilization. This would indicate that the Italian unions had not only successfully used institutionalized social partnership to secure their recognition and participation in the political process but also proven capable of linking the instrument of social partnership to their immediate organizational needs. Although social partnership may have distracted Italian unions from organizing new groups of workers, the overall picture (which may be fading in the meantime) of an integrated strategy of macro-level negotiations and micro-level mobilization remains an impressive example of political action, union democracy, maintenance of membership levels, and overall capacity building. According to our criteria, this is a prime example of integrating social partnership into a comprehensive approach to union revitalization in Europe's second-most strike prone country.

Since the 2001 election of the right-wing 'House of Freedom' coalition government, however, under the leadership of Silvio Berlusconi, the benefits of national-level tripartism for the unions have become more limited. There have been few opportunities to contribute to the ongoing reform project, and, as Lo Faro (2002) has shown, the government has used the European discourse of 'social partnership' to cover its unwillingness to involve unions in policy formation. Moreover, the comprehensive approach no longer functions as a unified policy of all three confederations. The CGIL has refused to participate in several joint pacts agreed upon by the other two confederations, including a restructuring plan at Fiat and the national tripartite Pact for Italy in 2002. It is still too early to determine whether the cooperative policies of the CISL and the UIL allow them to influence national policy-making, or whether their embeddedness obliges the leadership to pursue tripartism, despite the divisions in the labour camp and the demands of the government. Recent decisions by the government to raise the threshold of its readiness to reach unanimous agreement with the social partners - a shift from 'social concertation' to 'social dialogue' - and a proposal for restructuring the collective bargaining system in the direction of greater decentralization, have rekindled common strands of criticism among the confederations. The success of two general strikes in 2002 to protest about labour market reforms, however, suggests that the years of 
social partnership have not harmed the labour movement's ability to strike, even when the labour movement is divided, as in the case of the CGIL's mobilization against the Pact for Italy (Paparella and Rinolfi 2002).

While the proposal for decentralizing collective bargaining has been widely discussed, no significant refocusing to the local level has been initiated. Italian unions are strong in this regard, since union density and involvement in the factory committees remains quite high. Participation in factory committee elections has been at around 75 per cent, and at the most recent election, 90 per cent of the votes at over 4,000 workplaces went to the major union confederations (Locke and Baccaro 1999: 254). Although control of such a decentralization process and its use to strengthen direct membership participation could be to the advantage of revitalization efforts, unions fear that it would also leave them vulnerable to bargaining patterns that would allow more competition based on labour cost savings. Their exclusion from such local concertation efforts as the Milan Employment Pact (Regalia 2002), which represents a case of 'social partnership' without unions, is a further example of decentralization which has made them wary.

Finally, there is the issue of working with employers and central authorities for common public policy goals. The concertation successes of the $1990 \mathrm{~s}^{7}$ enabled the Italian unions to stem the tide of major membership decline faced in the other four countries, while participating in unpopular (but arguably necessary) decisions to reform the welfare state and the labour market; in response they won an expanded legal framework for collective bargaining and found a vehicle to communicate with and involve members. Hence, although subsequently diminished, the role of Italian unions in policymaking as partners with employers and the state did enhance their bargaining power and their political influence for a time. Whether the Italian unions will be open for partnerships with other non-state organizations remains an unanswered question at the moment.

\section{Spain}

Although the institutions of labour relations-widely applicable collective bargaining agreements, tripartite pacts, and statutory workplace committees - in post-Franco Spain have not had a long time to develop, they appear to be stable and conducive to social partnership. The activity of unions under Franco was circumscribed and then- opposition to the authoritarian government precluded any democratically founded partnerships. In the decade following Francos death (1975), the new government sought to prevent social unrest and to legitimize its democratization course via social pacts with employers and the unions. Although this cooperative approach aided the UGT (General Workers' Confederation) in its rivalry with the Workers' Commissions (CC.OO), and produced tangible gains in its early phase, its acceptance among the unions began to wane by the 1980s, when economic growth made wage restraint unfeasible for unionists in elected factory councils (Ruiz 2001). State interest in cooperation with the unions declined along with union membership, and a new wave of confrontation ensued which only resided after a change of government in the mid-1990s. Following the signing of agreements on social security and pensions in 1996, the way was opened for the successful negotiation of longawaited labour market reform (Andersen and Mailand 2002: 31) based in part on a series of pacts with labour and employers. The unions attached special importance to one of these, which strengthened the rights of Spain's temporary workforce, the largest in Europe, because they had been accused of representing the 'insiders' in a sharply segmented 
labour market (Fraile 1999).

Given the problem of segmentation in Spain, it is not surprising that unions have been keen on focusing attention on training and lifelong learning. National agreements in the late 1990s along with the development of a tripartite funding mechanism, have created institutional structures that allocate significant resources to workplace training and lifelong learning. In the meantime, however, the positive reception of these high- level national agreements within the unions has dissipated. Activities in this field have shifted to regional and local tripartite arenas, but the result has been regional funding disparities and unclear divisions of responsibilities. In addition, there has been a growing feeling among unionists that 'they are talked to, but not listened to' (Mailand and Andersen 2001: 8). Nevertheless, by promoting lifelong learning, Spain's unions have been able to develop an agenda connected to the concerns of those outside the group of'core' permanent employees.

The case of the Employment Pact is generally cited as a notable exception to this union criticism of recent tripartite developments. Using EU Structural Funds, a territorial employment pact was created in 1998 in Valles Occidental, an industrialized Catalonian county near Barcelona, which at the time had a comparatively high level of unemployment. 'Unions supported this pact because of the employment creation prospects it offered, because of the possibility to 'empower the processes of con- certation and social dialogue in order to affect both public policies and the wider dynamic of industrial relations', and, in addition, because of the financial resources available through participation (Lope, Gilbert, and de Villacian 2002: 27-29).

One reason why the Valles Occidental Pact has been given a generally favourable review in the literature (cf. Mailand and Andersen 2001: 12) is that the pact has linked the territorial with the company-level and has integrated collective bargaining structures into its overall framework. It has provided a solution to the challenges facing collective bargaining in Spain, including the fragmented and decentralized character of labour market regulation. It is a good example of how unions have pursued the 'widening of bargaining agendas around such issues as variable pay, functional and geographic mobility, working time, and the establishment of permanent employment' (Hamann and Martinez Lucio 2003: 67). Observers differ over the issue as to whether the still fragmented nature of the system is a possible advantage for the unions (Hamann 1998), or whether it makes the integration of micro- and macrolevel strategies more difficult (Artiles Martin and Moner 2003). Nevertheless, within the existing framework, accords on training have been reached and successfully implemented which identify unions with improvements in job market opportunities. Such 'partnerships at a distance' between unions and employers are beneficial to both the sectoral social dialogue (by adding a further layer of consultation) as well as to workers in SMEs in need of training access (Rigby 2003). As such, the unions are decidedly opposed to recent proposals to decentralize the institutions of continuous training because they regard such a step as destructive for the current inter-connection between these institutions and collective bargaining (Artiles Martin 2002). With bargaining still not well articulated at lower levels and employers tending to be unwilling to implement agreements at higher levels, unions are concerned about the actual impact of such partnerships at the workplace and in terms of their own revitalization efforts. In order to meet employer initiatives on the development of new forms of both workplace and human resource organization, unions are showing signs of considering employee involvement and development in more 
strategic terms (Martinez Lucio and Blyton 1995). In this sense, they maybe willing to bargain over longer-term restructuring agreements which allow for greater organizational and time flexibility in exchange for employment security. This would be a step towards constructing a new understanding of partnership in the Spanish workplace that could translate self-proclaimed bargaining successes and relatively widespread bargaining coverage into stronger workplace influence.

Caught between their institutionalized role in labour relations and a fragmented civil society and labour market, the unions are struggling to redefine their identity and devise new strategies in a contradictory environment both through mobilization and partnerships outside of the realm of collective bargaining such as the regional ones and those on training. Because of a general weakness of supportive organizations, however, these coalitions are transitory and do not develop into more long-term strategic alliances (Hamann and Martinez Lucio 2003: 65).

\section{CONCLUSION}

Can partnerships with employers help revitalize unions? Our answer is a heavily qualified affirmative, given the limitations of partnerships as a union strategy that we observe in a wide range of national contexts. We have argued that unions have to be able to integrate partnership activities into the full spectrum of the union s activities, that they need to link partnership to a broad agenda for social goods, and that they need institutional anchors. The national cases have shown, however, that there are often tensions among these factors. For example, the same strong German institutions that have furthered and solidified union power may also be stifling momentum towards union revitalization. Furthermore, unions are rarely able to realize all three of these factors simultaneously; at the same time, the cases have shown us that without all three, partnership is problematic for unions. Territorial employment pacts, for example, work in all of the countries to broaden what unions do and are tied to widely shared policy goals, but are rarely integrated with collective bargaining and sometimes-as in the case of the Milan Employment Pact-create problems for applying collective agreements.

Because a focus on partnerships with employers should not obscure the need for unions to find new agendas and organize new groups of workers, we have pointed to partnerships that contribute to broadening support for unionization. This is possible in all of the countries. Examples include German partnerships to use collective bargaining to conclude agreements addressing new issues; Italian partnerships to reform the welfare state and involve workers in the policy process; American and Spanish partnerships to improve workforce development (or 'lifelong learning) institutions; and British partnerships to improve contingent work.

As with other union revitalization phenomena, however, there is little evidence showing how widespread these kinds of partnerships are, and they all raise questions about their limitations. The case of the Seattle building trades, for example, illustrates a partnership linked to coalition-building with organizations located in working- class, minority neighbourhoods. It remains to be seen, however, whether the payoff from partnership at the local level can be sustained in the broader geo-political context. This case, as with most others, shows that revitalization is incremental, not wholesale, and limited to places that appear small in comparison to the national units of analysis this study is built around. Isolated 
instances cannot be expected to turn the overall tide of receding union density, they must be replicated and infused into the broader socio-political arena. By comparison, in countries where unions benefit from institutionalized frameworks, national social partnership currently suffers increasingly from a neo-liberal political turn and from the failure of unions to respond proactively. Thus, we find that integrating social partnership into a broad revitalization strategy is often frustrated by a combination of external challenges from government and employer strategies, and internal organizational problems of the unions.

In sum, despite the proliferation of literature about labour-management partnerships and the widespread belief that they ensure better outcomes for workers when unions are strong, there is still little understanding of how they can help unions revive themselves. In this chapter, we have developed a framework for considering the costs and benefits of social partnership for unions, an important project, given the strategy's importance for so many European and American unions. We find that partnerships built on broadly appealing policy agendas, an institutionalized role for unions, and strong union capacities produce detectable increases in bargaining power, membership density, or political power. Unfortunately, the vast majority of partnerships lack those qualities and tend to feed into the process of union decline.

\section{Notes}

1. Cooperation has, in our usage, a much broader definition than partnership. Cooperation occurs in nearly every workplace and bargaining relationship, even where it is not formalized as a partnership or shaped by a union capable of wielding countervailing power.

2. While making no claim to being comprehensive, the following section will enable the reader to pick up our arguments in their relationship to selected bodies of English-language literature on social partnership and labourmanagement partnership in the various countries, as well as the applicable concepts in the union revitalization literature. This approach does not do justice to the existing German, Spanish, and Italian literature. However, in addition to the obvious argument of limited space, it is also not the intention of this chapter to provide such an extensive treatment.

3. For evidence on the widespread use of PLAs, see the anti-PLA website operated by the Associated Builders and Contractors (Anonymous 2003). The agreement exists in the urban strongholds of the labour movement such as Boston, Chicago, and Detroit; in upcoming union cities like Las Vegas and Los Angeles; and even on federal government construction projects in the hinterlands of Idaho and eastern Washington.

4. While the term has appeared often in the titles of publications in recent years, most authors do not attempt to define its usage.

5. VW is a notable exception to this because the company is not a member of the employers' association and therefore it negotiates all contracts directly with the IG MetaU. The union has an intensive working arrangement with the various works councils at the company.

6. In late $1999, \mathrm{VW}$ proposed hiring 5,000 unemployed workers at a fixed monthly pay rate of DM 5,000 (ca. € 2,556) 
to produce a new model. Under this scheme, working time would not be fixed but employees would be obliged to work as long as necessary (up to the statutory maximum working week of 48 hours) to reach a certain production target without any overtime or other extra pay. Moreover, Saturdays were to become a regular working day. Two years later the company concluded a set of agreements with the IG Metall for new pay and working time provisions below the level set by the main VW company agreement, but equivalent to the level of the sectoral cohective agreement for metalworking. Furthermore, the agreements include innovative provisions on continuing training, work organization and co-determination rights (Schulten 2001).

7. Under the subsequent government, the unions negotiated a series of national pacts. The first two pacts (1992 and 1993) replaced the wage indexation system (a popular program which had created problems both for employers and unions (Locke and Thelen 1995) with a new system of cohective bargaining operating simultaneously at the local and national levels. Subsequent pacts dealt with other controversial issues such as pension reform (1995) and contingent workers (1996), in both cases, making the labour market more flexible while providing protections for workers and some control to unions. The 1996 agreement also encouraged territorial partnerships involving a large number of stakeholders (banks, universities, cooperatives, nonprofits, etc.) to supplement collective bargaining and promote economic development in Southern Italy. The 'Christmas Pact' of 1998 further expanded the range of issues in which the government consulted employers associations and unions, and devolved certain functions to the social partners for bipartite regulation.

\section{References}

Ackers, P. and Payne, J. (1998). 'British Trade Unions and Social Partnership: Rhetoric, Reality, and Strategy'. International Journal of Human Resource Management, 9/3: 529-50.

Andersen, S. and Mailand, M. (2002). The Role of Employers and Trade Unions in Multipartite Social Partnerships. Copenhagen: The Copenhagen Centre.

Arrowsmith, J. (2002). United Kingdom. Partnership 'Alive and Well'. EIRO, available at www.eiro.eurofound.ie/2002/05/Feature/UK0205103F.html edn.

Artiles Martin, A. (2002). 2001 Annual Review for Spain, EIRO, available at www.eiro. eurofound.ie/about/2002/01/feature/ES0201152F.html edn.

Artiles Martin, A. and Moner, R. A. (2003). 'Between Decentralisation and Centralisation of Collective Bargaining'. Industrielle Beziehungen, 10/1: 64-96.

Baccaro, L. (2001). “"Aggregative” and "Deliberative” Decision-making Procedures: 
A Comparison of Two Southern European Factories'. Politics and Society, 29/2: 243-71.

(2002). 'The Construction of "Democratic" Corporatism in Italy'. Politics and Society,

30/2: 327-57.

Carrieri, M., and Damiano, C. (2003). 'The Resurgence of the Italian Confederal Unions:

Will It Last?'. European Journal of Industrial Relations, 9/1: 43-59.

Hamann, K., and Turner, L. (2003). 'The Politics of Labour Movement Revitalization:

The Need for a Revitalized Perspective'. European Journal of Industrial Relations, 9/1:119-33.

Banks, A. and Metzgar, J. (1989). 'Participating in Management: Union Organizing on a New Terrain'. Labor Research Review, 14: 1-56.

Behrens, M., Fichter, M., and Frege, C. M. (2003). 'Unions in Germany: Regaining the Initiative?' European Journal of Industrial Relations, 9/1: 25-42.

Brecht, H. and Höland, A. (2001). 'Gewerkschaften und politische Bündnisse'. WST Mitteilungen, 54/8: 501-7.

Christopherson, S. and Storper, M. (1987). 'The Effects of Flexible Specialization on the Labor Market and Industrial Politics'. Industrial and Labor Relations Review, 42: 331-47.

CNA (2002). Kaiserwatch, www.calnurses.org.

Deakin, S., Hobbs, R., Konzeimann, S., and Wilkinson, F. (2002). 'Partnership, Ownership and Control: The Impact of Corporate Governance on Employment Relations'. Employee Relations, 24/3: 335-52.

Eaton, A. and Kriesky, J. (2001). 'Union Organizing Under Neutrality and Card Check Agreements'. Industrial and Labor Relations Review, 55/1: 42-59.

Erlich, M. (1986). With our Hands: The Story of Carpenters in Massachusetts. Philadelphia, PA: Temple University Press.

European Commission (2002). Industrial Relations in Europe 2002. Luxembourg: Office for Official Publications of the European Communities.

Fraile, L. (1999). 'Tightrope: Spanish Unions and Labor Market Segmentation', in A. Martin and G. Ross, (eds.), The Brave New World of European Labor. New York: Berghahn Books.

Frost, A. (2001). 'Creating and Sustaining Local Union Capabilities: The Role of the National Union'. Relationnes Industrielles, 56/2: 307-35.

Gerlach, F. and Ziegler, A. (2000). 'Territoriale Beschaeftigungspakte in Deutschland-Neue Wege der Beschaeftigungsfoerderung?' WSI-Mitteilungen, 53/7: 430-7.

Gray, G., Myers, D., and Myers, R (1999). 'Cooperative Provisions in Labor Agreements: a New Paradigm?'. Monthly Labor Review, 122/1: 29-45.

Guest, D. E. and Peccei, R. (2001). 'Partnership at Work: Mutuality and the Balance of Advantage'. British Journal of Industrial Relations, 39/2: 207-36.

Haddock, B. (2002). 'Italy in the 1990s: Policy Concertation Resurgent', in S. Berger and H. Compston (eds.), Policy Concertation and Social Partnership in Western Europe. Lessons for the 21st Century. New York: Berghahn.

Hall, P. A. and Soskice, D. (2001). Varieties of Capitalism: The Institutional Foundations of Comparative Advantage. Oxford: Oxford University Press.

Hamann, K. (1998). 'Spanish Unions: Institutional Legacy and Responsiveness to Economic and Industrial Change'. Industrial and Labor Relations Review, 51/3: 424-44.

and Martinez Lucio, M. (2003). 'Strategies of Union Revitalization in Spain: Negotiating

Change and Fragmentation'. European Journal of Industrial Relations, 9/1: 61-78.

Heery, E. (2002). 'Partnership versus Organizing: Alternative Futures for British Trade Unionism'. Industrial Relations Journal, 33/1: 20-35. 
Kelly, J., and Waddington, J. (2003). 'Union Revitalization in Britain'. European Journal of Industrial Relations, 9/1: 79-97.

Conley H., Delbridge, R., and Stewart, P. (2004). 'Seeking Partnership for the Contingent

Workforce', in M. Martinez Lucio and M. Stuart (eds.), Assessing Partnership: The Prospects for and Challenges of Modernizing Employment Relations. London: Routledge.

Heidemann, W. (2001). 'Bausteine für lebenslanges Lernen: Tarifvertrag zur Weiterbildung'. Die Mitbestimmung, 47/10: 58-9.

Heidenreich, M. (2001). 'Die Zukunftsfähigkeit der industriellen Beziehungen. Das Beispiel des VW-Tarifmodells'. Gegenwartskunde. Zeitschrift für Gesellschaft, Wirtschaft, Politik und Bildung, 50/3: 353-62.

Herod, A. (2001). Labor Geographies. New York: Guilford Press.

Huber, B. and Hofmann, J. (2001). 'Der Tarifvertrag zur Qualifizierung in der Metall- und Elektroindustrie BadenWürttembergs'. WSI-Mitteilungen, 54/8: 464-6.

Hyman, R. (2001a). 'Some Problems of Partnership and Dilemmas of Dialogue', in C. Kjaergaard and S. Westphalen (eds.), From Collective Bargaining to Social Partnerships: New Roles of the Social Partners in Europe. Copenhagen: The Copenhagen Centre.

(2001b). Understanding European Trade Unionism: Between Market, Class, and Society.

London: Sage.

IG Chemie (2003). 8 May 2003-last update, Chemie-Tarifpaket 2003. 2,6 Prozent mehr Entgelt, VIII/30, available at www.igbce.de/IGBCE/CDA/Artikelseite/0,2888,artikelld\%3D6250,00.html [18 June 2003],

Juravich, T. (1998). 'Employee Involvement, Work Reorganization, and the New Labor Movement: Toward a Radical Integration'. New Labor Forum, Spring/Summer Issue: 84-91.

Katz, H. C. (1985). Shifting Gears: Changing Labor Relations in the U.S. Automotive Industry. Cambridge, MA: MIT Press.

(1993). 'The Decentralization of Collective Bargaining: A Literature Review and

Comparative Analysis'. Industrial and Labor Relations Review, 47/1: 3-22.

Kelly, J. (1998). Rethinking Industrial Relations. London: Routledge.

(2004). 'Social Partnership Agreements in Britain: Labor Cooperation and Compliance'.

Industrial Relations, 43/1: 267-92.

Kjaergaard, C. (2001). 'From Collective Bargaining to Social Partnerships', in C. Kjaergaard and S. Westphalen (eds.), From Collective Bargaining to Social Partnerships: New Roles of the Social Partners in Europe. Copenhagen: The Copenhagen Centre.

Klare, K. (1988). 'The Labor-Management Cooperation Debate: A Workplace Democracy Perspective'. Harvard Civil RightsCivil Liberties Law Review, 23: 39-83.

Kochan, T. A., Katz, H. C, and McKersie, R. (1986). The Transformation of American Industrial Relations. New York: Basic Books.

Leroy, G. (2002). 'Smart Growth for Cities: It's a Union Thing'. WorkingUSA, 6/1: 56-76.

Linder, M. (1999). Wars of Attrition. lowa City: Fanpihuä Press.

Lo Faro, A. (2002). 'Fairness at Work? The Italian White Paper on Labour Market Reform'. Industrial Law Journal, 31/2: 190-98.

Locke, R. (1992). 'The Demise of the National Union in Italy: Lessons for Comparative Industrial Relations Theory'. Industrial and Labor Relations Review, 45/2: 229-49.

and Baccaro, L. (1999). 'The Resurgence of Italian Unions?', in A. Martin and G. Ross 
(eds.), The Brave New World of European Labor. New York: Berghahn Books, 217-68.

and Thelen, K. (1995). 'Apples and Oranges Revisited: Contextualized Comparisons and

the Study of Comparative Labor Politics'. Politics and Society, 23/3: 337-67.

Lope, A., Gilbert, F., and de Villacian, D. (2002). The Local Regulation of the New Forms of Employment and Work. The Case of Catalonia. Milan: LOCLEVCONC-Project on Local Level Concertation.

Mailand, M. and Andersen, S. K. (2001). Spain. Social Partnerships in Europe. The Role of the Employers and Trade Unions. Copenhagen: The Copenhagen Centre.

Martinez Lucio, M. and Blyton, P. (1995). 'Constructing the Post-Fordist State? The Politics of Labour Market Flexibility in Spain'. West European Politics, 18/2: 340-60.

and Stuart, M. (2002). 'Assessing Partnership: the Prospects for, and Challenges of

Modernisation'. Employee Relations, 24/3: 252-61.

Mauer, A. and Seifert, H. (2001). 'Betriebliche Beschäftigungs- und Wettbewerbsbündnisse- Strategie für Krisenbetriebe oder neue regelungspolitische Normalität?'. WSI-Mitteilungen, 54/8: 490-500.

Mills, N. (2001). 'New Strategies for Union Survival and Revival'. Journal of Labor Research, 22/3: 599-613.

Müller-Jentsch, W. (1999). Konfliktpartnerschaft. Akteure und Institutionen der industriellen Beziehungen. Schriftenreihe Industrielle Beziehungen 1, 3rd edn., München-Mering: Rainer Hampp Verlag.

Munro, A. and Rainbird, H. (2000). 'The New Unionism and the New Bargaining Agenda: UNISON-Employer Partnerships on Workplace Learning in Britain'. British Journal of Industrial Relations, 38/2: 223-40.

Neumann, G. (2000). 'Bündnisse für Arbeit in Deutschland-Ein Überblick'. WSI- Mitteilungen, 53/7: 419-29.

Northrup, H. (1997). 'Construction Programs to Regain Jobs: Background and Overview'. Journal of Labor Research, 18/1: $1-15$.

Paparella, D. and Rinolfi, V. (2002). CGIL Organises General Strike. EIRO Online, 14 March 2002. www.eiro.eurofound.ie/2003/03/InBrief/IT0303101N.html edn.

Parker, M. and Slaughter, J. (1994). Working Smart: A Union Guide to Participation Programs and Reengineering. Detroit: Labor Notes.

(1997). 'Advancing Unionism on the New Terrain', in B. Nissen, (ed.), Unions and

Workplace Reorganization. Detroit: Wayne State University Press.

Preuss, G. and Frost, A. (2003). 'The Rise and Decline of Labor-Management Cooperation'. California Management Review, 45/2: 85-106.

Pries, L. (2002). '5000 X 5000: Ende gewerkschaftlicher Tarifpolitik oder innovativer betrieblich-tariflicher Sozialpakt?'. Industrielle Beziehungen, 9/2: 222-35.

Regalia, I. (2002). Introduction and Summary of Main Findings. Milan: LOCLEVCONC Project on Local Level Concertation.

Rehder, B. (2002). The Interaction of Pacts for Employment and Competitiveness and the Collective Bargaining System in Germany. Cologne: Max Planck Institut fur Gesellschaffsforschung, Unpublished Manuscript.

Reynolds, D. B. (2002). Taking the High Road: Communities Organize for Economic Change. Armonk, NY: ME Sharpe.

Rigby, M. (2003). 'Spanish Trade Unions and the Provision of Continuous Training: Partnership at a Distance'. Human Resources Abstracts, 38/1: 5-136.

Ruiz, J. A. (2001). 'Without Unions, but Socialist: The Spanish Socialist Party and its Divorce from its Union Confederation (1982-96)'. Politics and Society, 29/2: 273-96.

Schmidt, W. (1985). Sozialer Frieden und Sozialpartnerschaft. Kapital und Arbeit in der Gesellschaftspolitik der westdeutschen Christdemokraten 1945 bis 1953. Frankfurt (Main): Lang.

Schroeder, W. and Weinert, R. (1999). 'Managing Decentralization: The Strategy of Institutional Differentiation in German 
Industrial Relations'. German Politics and Society, 17/4: 52-73.

Schulten, T. (2001). Agreements Signed on Volkswagens 5000X5000 Project, www.eiro. euro found, ie/about/2001 /09/feature/DE0109201 F.html edn.

Streeck, W. (1984). Industrial Relations in West Germany: A Case Study of the Car Industry. London: Heinemann.

Stuart, M. and Martinez Lucio, M. (2002). 'Social Partnership and the Mutual Gains Organization: Remaking Involvement and Trust at the British Workplace'. Economic and Industrial Democracy, 23/2:177-200.

Teague, P. (1989). 'The British TUC and the European Community'. Millennium: Journal of International Studies, 18/1: 2945.

Thelen, K. (2001). 'Varieties of Labor Politics in the Developed Democracies', in P. A. Hall and D. Soskice (eds.), Varieties of Capitalism. Cambridge: Cambridge University Press.

Tondorf, K. (2001). 'Gender Mainstreaming in der Tarifpolitik'. WSI-Mitteilungen, 54: 434-41.

Turner, L. (1991). Democracy at Work. Ithaca, NY: ILR Press.

(1998). Fighting for Partnership. Ithaca, NY: ILR Press.

WAI (2000). High Road Partnership Report. Washington, DC: AFL-CIO.

(2002). Helping Low-Wage Workers Succeed Through Innovative Union Partnerships.

Washington, DC: AFL-CIO.

Walton, R., Cutcher-Gershenfeld, J., and McKersie, R. (1994). Strategic Negotiations: A Theory of Change in LaborManagement Relations. Ithaca, NY: ILR Press.

Wells, D. M. (1987). Empty Promises: Quality of Working Life Programs and the Labor Movement. New York: Monthly Review Press. 